\title{
The Past and Future of the European Union Internal Market - Visegrad Group Perspective
}

\section{Silvia RUČINSKÁ, Miroslav FEČKO}

\author{
Fakulta verejnej správy, Univerzita Pavla Josefa Šafárika v Košiciach \\ Faculty of Public Administration, Pavol Jozef Šafárik University in Košice, \\ Popradská 66, 04132 Košice, Slovakia \\ silvia.rucinska@upjs.sk \\ Fakulta verejnej správy, Univerzita Pavla Josefa Šafárika v Košiciach \\ Faculty of Public Administration, Pavol Jozef Šafárik University in Košice, \\ Popradská 66, 04132 Košice, Slovakia \\ miroslav.fecko@upjs.sk
}

\section{Introduction}

After the 2004 and later European Union (EU) enlargements, when also the EU Internal Market has been expanded, the EU and its Internal Market became more interconnected in a wider European sense and started to form itself not only in the terms of the West European country's perspectives. ${ }^{1}$ Despite the fact that the Visegrad Group has been formed as a political project ${ }^{2}$ and as a grouping without an institutional form ${ }^{3}$, it has a significant place not only in the Central European territory, but also within the whole EU Internal Market.

Similar historical, political, economic and society conditions of country's development in Central Europe after 1989 have led to a natural effort of these countries to search for cooperation possibilities and to exchange each other's experiences. The declaration establishing the Visegrad Group in 1991 has also highlighted a similarity between the Czech and Slovak Federative Republic, Poland and Hungary, as of countries with a common history of centrally planned economies and striving for a successful transformation process. Identical objectives and similar ways for achieving them have brought the same tasks for the Central Europe countries. ${ }^{4}$

Internal Market is the key term of this article, but it isn't used in the literature uniformly though. Some authors use the term single market, others prefer to use the term internal market, or these two terms are used synonymously. Internal market is defined by the primary EU law, in the Treaty on European Union and in the Treaty on the Functioning of the European Union. Treaty on European Union points out that the EU Member States together

1 DELANTY, Gerard: Introduction: Perspectives on crisis and critique in Europe today, in: European Journal of Social Theory, 17, 2014, 3, 209.

2 SOBJÁK, Anita: Rethinking the future of the Visegrad group at a time of heated debate on the future of the EU, in: The Polish Quarterly of International Affairs, 21, 2012, 4, 122-139, 123.

3 CZYZ, Anna: What is the Future of the Visegrad Group as an Example of Regional Cooperation, in: Studia Universitatis Babes-Bolyai, Studia Europaea, 52, 2007, 2, 131-144.

4 Deklarace o spolupráci České a Slovenské Federativní Republiky, Polské republiky a Mad’arské republiky na cestě evropské integrace, 1991. 
form the internal market. ${ }^{5}$ Specification of the character and content of the internal market is included in the Treaty on the Functioning of the European Union, in which the internal market is mentioned in the context of EUs exclusive competences and of the need for adopting common competition rules. ${ }^{6}$ Subsequently, the internal market is defined as an area, where joint EU competences are applied. ${ }^{7}$ The internal markets substance as of the territory of four economic freedoms (free movement of goods, services, capital and person) is incorporated in the third part, chapter I of the Treaty on the Functioning of the European Union. ${ }^{8}$ Also article 115, article 116, article 118 and article 134 of the Treaty on the Functioning of the European Union are oriented on the legislative, institutional and political ensuring and supporting of internal markets functioning. Based on the differences in using the terminology in the literature and taking into account the primary EU law which specifically defines and uses the term Internal Market, we will prefer to use the term EU Internal Market ${ }^{9}$ in the following text of the article. Our intention in this regard is not to provide an in depth analysis of the terminology, but to clarify our decision in using EU Internal Market, as it is also used by the EU primary law.

This article isn't primarily oriented on the history of the Visegrad Group's development ${ }^{10}$ or on the European integration history after the World War II and of the establishment of the EU. The main orientation is focused on the identification of the important historical milestones of the EU Internal Market's beginning and development and on the position of the Visegrad Group countries within this process. It is clear that these historical milestones took place in the context of the integration process in Europe, which after 2004 the Visegrad Group countries have also joint. EU Internal Market can't be considered as a completed project. It is still a continuously forming territory of the free movement of goods, services, capital and person. The beginnings of this process go back to the formulation of the first ideas of a common market between several countries after the World War II and continue to the present.

The subject of research in this article is the role of the Visegrad Group countries in the EU Internal Market completion, their ability and willingness to actively participate within the EU Internal Market development or just to accept the model proposed by the older and original EU Member States. The first step will be to introduce the progression of first ideas and actions towards the EU Internal Market's creation. The analysis of supporting measures and strategies aimed at the EU Internal Market completion will follow. Following the EU Internal Market context, the analysis will be oriented onto the Visegrad Group countries, on

5 Treaty on European Union, Article 3, Section 3.

6 Treaty on the Functioning of the European Union, Article 3, Section 1.

7 Treaty on the Functioning of the European Union, Article 4, Section 2.

8 Treaty on the Functioning of the European Union, Article 26, Section 2.

9 For more about the development, process and barriers of the EU Internal Market see: RUČINSKÁ, Silvia FEČKO Miroslav: Vnútorný trh Európskej únie - sme v súčasnosti bez hraníc?, in: Integrovaná Evropa současnosti a budoucnosti - Reflexe třiceti let od podpisu Schengenské úmluvy, PÁNA, Lubomír a kol., České Budějovice 2015, 55-63.

10 For more about the character of cooperation, development, history and present of the Visegrad Group see: CZYZ, 2007; DANGERFIELD, Martin: V4: A new brand for Europe? Ten years of post-accession regional cooperation in central Europe, in: The Poznan University of Economics Review, 14, 2014, 4, 71-90.; ROSTEKOVÁ, Maria - ROUET, Gilles: The Visegrád Group - a Model to Follow?, in: Politeja, 28, 2014, 181-193. 
their role in the EU Internal Market completion process, with a specific focus on the period before the $\mathrm{EU}$ accession and after the completion of the EU accession process.

\section{European Integration Process towards the EU Internal Market}

The process towards explicit anchoring of the EU Internal Market idea and towards concrete steps for its development, needs to be considered not only in the context of the European Communities integration process, which led to the creation of the EU in its present form. Important in this regard are also historical milestones, which explicitly did not determine goals in the EU Internal Market creation context, but which fit into the process. The analysed historical phases are oriented mainly on the formation of ideas regarding European country's closer cooperation in the beginning of the $20^{\text {th }}$ Century, which had a form of general declarations or in the opposite way real actions proposals and which were a necessary part of the EU Internal Market formation gradual process.

After World War I, Richard Nicolaus Coudenhove-Kalergi formulated the idea of a Pan-European union. ${ }^{11}$ Aristide Briand as a Pan-European follower presented in 1929 a proposal to create a European Federative Union. ${ }^{12}$ In 1930 Briand elaborated a European Union Organisation Memorandum. ${ }^{13}$ Janků and Janků have stated that Briand's initiative was an important source of new integration processes in the post-war period. ${ }^{14}$ Presented vision by Briand should have allowed cooperation in economy, finance, transport, labour based relations, health, culture, education and other. ${ }^{15}$ Tichý et al. have in this regard noted the intention to liberalize free movement of goods, person and capital, which later proved to be one of the fundamental economic freedoms of the EU Internal Market. ${ }^{16}$ Winston Churchill played also an important role, when he has proposed the establishment of the United States of Europe and in 1948 he "proposed to establish the European Parliament and thus gave a decisive impetus to the creation of the Council of Europe" ${ }^{17}$ An example for a close economic cooperation of several countries in the form of a customs union was the establishment of Benelux in 1944. ${ }^{18}$ The economic cooperation of Benelux expanded in 1948 in the form of the Western Union, which was established together with France and Great Britain through the so called Brussels Treaty. ${ }^{19}$ The ongoing integration efforts led to an enlargement of the Western Union with Germany and Italy, when in 1954 by signing the so called Paris Agreements the original Brussels Treaty was modified. According to the consolidated Brussels Treaty, the Western Union transformed into West-European Union,

11 KALESNÁ, Katarína - HRUŠKOVIČ, Ivan - ĎURIŠ, Michal: Európske právo, Bratislava 2011, 247.

12 Ibidem.

13 HURNÁ, Lucia - RUSIŇÁK, Peter: Právo Európskej únie, Bratislava 2010, 396.

14 JANKUீ, Martin - JANKÜ, Linda: Politické a právní základy evropských integračních seskupení, Praha 2010, 256.

15 STRÁŽNICKÁ, Viera: Európska integrácia a právo Európskej únie, Bratislava 2009, 312.

16 TICHÝ, Luboš et al.: Evropské právo, Praha 2011, 953.

17 Ibidem, 9; HURNÁ - RUSIŇÁK, 2010.

18 KALESNÁ - HRUŠKOVIČ - ĎURIŠ, 2011.

19 JANKUீ - JANKUீ, 2010. 
which focused on economic, social, cultural and defence cooperation. ${ }^{20}$

In terms of the integration steps towards the establishment of the EU and EU Internal Market, the activities of France and of its main political personalities in the post-war period had a key role. It was obvious, that any post-war cooperation what so ever had to be done based on and ensuring a peaceful cooperation of nations which had gone through two world wars. Based on this, the so called Schuman Declaration was introduced in 1950, which highlighted France and Germany as the main European nations to bear the idea of integration. ${ }^{21}$ This role of Germany and France was characteristic especially given the history of these countries, where the rivals had to become the unifiers of the post-war Europe. The Schuman Declaration presented a vision of cooperation in common approaches regarding the production of steel and coal and to limit their misuse for military reasons.

In 1951 the Schuman Declaration resulted into the establishment of the European Coal and Steal Community (ECSC), by signing the Treaty establishing the ECSC between France, Germany, Italy and Benelux. ${ }^{22}$ Despite the fact that the ECSC aimed for integration in specific materials, it laid the foundations for a later formation of a European community of nation's common market. The common market is in the Treaty establishing the ECSC mentioned several times, where for example in article 1 is stated, that ECSC "is based on a common market, pursues common objectives and has common institutions", or in the article 2 "... in accordance with a common member state's economy and based on a common market ...". The Treaty establishing the ECSC in article 4 further specified the vision of a common market, by anchoring a prohibition of customs duties and similar measures for imports and exports, quantitative trade restrictions, antidiscrimination principles, state subsidies reduction, prohibition of additional obligations and other restrictive practices to the detriment of markets. ECSC was according to the article 97 of the Treaty establishing the ECSC established only for a limited period of fifty years. ${ }^{23}$

The positive experience with the ECSC has naturally led to an effort and willingness to further expand the areas of cooperation and of the number of member states. Common market of coal and steel had positive impacts on trade relations of the participating countries and thus also on their economic growth. ${ }^{24}$ The next development in 1957 in Rome resulted in signing of two treaties, the Treaty establishing Euroatom and the Treaty establishing European Economic Community (EEC), for which the name Rome Treaties was used. In article 2 of the Treaty establishing EEC was the common market highlighted as an essential tool and a means to achieve the community's objectives, which had to be development of economic activities, continual and balanced growth, stability, improving the standards of living and the cooperation in member states. The effort for progress in economic integration was reflected in the article 8 of the Treaty establishing EEC, where the period of twelve years was set, within which the necessary activities to establish the common market should

20 Text of the Modified Brussels Treaty 1954, online: http://www.weu.int/Treaty.htm\#1, Article I, Article II, Article III, Article V.

21 The Schuman Declaration 1950, in: From The Schuman Declaration to the birth of the ECSC: The role of Jean Monnet, PIODI, Franco (ed.), Luxemburg 2010, 6, 9-11.

22 JANKUீ, Martin - JANKU゚ Linda: Právo EU po Lisabonské smlouvě, Ostrava 2012, 275.

23 Vertrag über die Gründung der Europäischen Gemeinschaft für Kohle und Stahl 1951.

24 LIPKOVÁ, Ĺudmila a kol.: Európska únia, Bratislava 2011, 448. 
have been done. Explicit expression and further elaboration of economic freedoms in separate articles was also important from the common markets' perspective. ${ }^{25}$ ECSC, EEC and Euroatom were connected through the same member states, similar institutions and their activities were also increasingly overlapped. According to Bracjun, the parallel existence of three institutional systems with own rules and approaches was ineffective. The solution was the merging of all three existing communities through the Merger Treaty in 1965, whereby they became known as the European Communities. ${ }^{26}$

European Communities had a difficult task, to prepare conditions and to realize needed steps for a functioning common market. To meet these objectives, it was necessary to draft strategic documents to guide actions in this area and to revise the founding treaties. From the perspective of the common market a document called Completing the Internal Market, White Paper from the Commission to the European Council (the so called White Paper) signed by the Commission of the European Communities in 1985 had a special significance. According to the Commission of the European Communities, the White Paper defined the objective to create a functioning internal market till 1992.27 At the same time the objective was set, that this market should be an expanding market, flexible and using the production factors of the members states in the biggest possible extent. For this to be reached, the White Paper incorporated several concrete steps and measures, which were a part of the White Paper's annex with the total number exceeding three hundred. These measures were directed to the internal market without any barriers of physical, technical and tax character within the free movement of goods, services, capital and person. Regarding the need to take real actions not only political declarations, the White Paper was also important because it defined a time schedule for every specified measure. Single European Act adopted in 1986, which was the first revision of the Founding Treaties, also referred to the objective to create the internal market till the end of 1992. According to the Single European Act, the internal market was considered as "territory without internal borders, in which the free movement of goods, person, services and capital is ensured in accordance with the provisions of the Treaty". ${ }^{28}$

The role of the Single European Act was from the perspective of the EU Internal Market creation crucial. ${ }^{29}$ Single European Act launched a broad legislative process of adoption of directives and regulations concerning the EU Internal Market ${ }^{30}$, but in early 1993 the EU Internal Market couldn't be considered as completely built. A period of continued political efforts towards the development of the EU Internal Market followed.

25 Treaty Establishing the European Economic Community 1957.

26 BRACJUN, Anatolij: Hospodárska politika Európskej únie, Bratislava 2008, 224.

27 Completing the Internal Market. White Paper from the Commission to the European Council, Commission of the European Communities, document COM (85), 310 final, Brussels 1985, online: http://aei.pitt.edu/1113/1/ internal_market_wp_COM_85_310.pdf.

28 Single European Act 1986, Article 13.

29 HOWARTH, David - SADEH, Tal: The ever incomplete single market: differentiation and the evolving frontier of integration, in: Journal of European Public Policy, 17, 2010, 7, 922-935; MCNAUGHTON, Anne: Integrating services markets: a comparison of European Union and Australian experiences, in: Australian Journal of International Affairs, 65, 2011, 4, 454-468.

30 LOCKWOOD, Ben - MIGALI, Giuseppe: Did The Single Market Cause Competition in Excise Taxes? Evidence From EU Countries, in: Economic Journal, 119, 2009, 536, 406-429. 
All partial steps of EU Internal Market's creation until 2004 took place in a close group of original EU Member States ${ }^{31}$ and without the Visegrad Group countries. In this regard was the process of building up the EU Internal Market a parallel process and an alternative to the socialistic countries. Also every EU enlargement that took place up to 1995, when each of them meant an increase of one, two or maximum three new countries at once, was also an de facto enlargement of the EU Internal Market. The accession of the Visegrad Group countries in 2004 as one of ten new EU Member States started a new phase in building up the EU Internal Market, because this enlargement was the biggest one in EU Internal Market history and because post-socialistic countries for the first time have joint the EU Internal Market. The process of building up the EU Internal Market has acquired a new dynamism, it was necessary to deal with new convergence challenges.

\section{EU Internal Market Strategies}

The process of European integration towards the EU Internal Market has shown that the defined objective to build up the EU Internal Market until 1993 wasn't achieved to the extent as expected. The effort to complete the EU Internal Market was still a political priority of the EU Member States though. ${ }^{32}$ The expression of such a political priority were strategic documents, guidelines, calls, statements of the relevant EU bodies and of their representatives, which argued in favour of the need to a barrier-free EU Internal Market and which pursuing this objective defined necessary steps and measures needed to be realized at the EU and EU Member States level.

Several action plans, strategies, priorities, recommendations between 1997 and 2009 followed the stated overall objective do build up the EU Internal Market, as for example: 1997 Action Plan for the Single Market ${ }^{33}, 1999$ The strategy for Europe's Internal Market ${ }^{34}, 2003$ Internal Market Strategy - Priorities 2003-200635, 2007 A single market for $21^{\text {st }}$ century Europe $^{36}, 2009$ Commission recommendations on measures to improve the functioning of

31 From six founding member states in 1957 to the $15 \mathrm{EU}$ member states after enlargement in 1995.

32 RUČINSKÁ, Silvia - FEČKO Miroslav: Vnútorný trh Európskej únie z pohladu jeho dvadsatročnej existencie, in: Aktuálne problémy a výzvy verejnej správy: recenzovaný zborník z vedeckej konferencie s medzinárodnou účast'ou konanej dňa 21. novembra 2012 v Košiciach, Univerzita Pavla Jozefa Šafárika v Košiciach, Fakulta verejnej správy, Košice 2012, 205-213.

33 Action Plan for the Single Market, Communication of the Commission to the European Council, European Commission, document CSE (97) 1 final, Brussels 1997, online: http://ec.europa.eu/internal_market/strategy/ docs/plan_en.pdf.

34 The strategy for Europe's Internal Market, Communication from the Commission to the European Parliament and the Council, European Commission, document COM (1999) 624 final/2, Brussels 1999, online: http://eur-lex. europa.eu/legal-content/EN/TXT/PDF/ ?uri=CELEX:51999DC0624\&qid=1473684859494\&from=EN.

35 Internal Market Strategy - Priorities 2003-2006, Communication from the Commission to the Council, the European Parliament, the European Economic and Social Committee and the Committee of the Regions, European Commission, document COM (2003) 238 final, Brussels 2003, online: http://eur-lex.europa.eu/legal-content/EN/ TXT/PDF/?uri=CELEX: 52003DC0238\&qid=1473685001362\&from=EN.

36 A single market for $21^{\text {st }}$ century Europe, Communication from the Commission to the European Parliament, the Council, the European Economic and Social Committee and the Committee of the Regions, European Commission, document COM (2007) 724 final, Brussels 2007, online: http://eur-lex.europa.eu/legal-content/EN/TXT/ PDF/?uri=CELEX: 52007DC0724\&qid= 1473685114116\&from=EN. 
the single market ${ }^{37}$.

In 2010 another political initiative followed, which resulted in to a report elaborated by Mario Monti, in the form of the New Strategy for the Single Market at the Service of Europe's Economy and Society (New Strategy for the Single Market). Monti has stated that the New Strategy for the Single Market should be considered as a tool to revive the political efforts of the EU and of its Member States, towards the completion of the EU Internal Market. ${ }^{38}$ Monti also stated that the existing big number of regulations and directives, which in different extent and in different detail regulate every area of the EU Internal Market, doesn't need new legislative provisions. As seen by Monti, it was necessary to revive political efforts, so that the EU Internal Market could exploit the potential it had. Monti's argumentation in favour of the New Strategy for Single Market was mainly because of the weakening of the political and social support for the EU Internal Market; disproportionate development of different EU Internal Market areas; lack of attention in new areas, given the changing economic and socio-political conditions; weakening of the political efforts resulting from false sense of a finished EU Internal Market completion. ${ }^{39}$ Another important factor was the necessity for a comprehensive approach, what the New Strategy for Single Market should have. Such an approach should incorporate several policies, including those which haven't traditionally been seen as a part of the EU Internal Market completion. Monti wasn't in this sense speaking only about competition policy, which was understood as a strong and fundamental tool for market integration, but he also highlighted "industrial, consumer, energy, transport, digital, social, environment, climate change, trade, tax and regional policies, but also policies that seem more remote from economic aspects, such as justice and citizenship". ${ }^{40}$

European Commission introduced Single Market Act - Twelve levers to boost growth and strengthen confidence (Single Market Act) as another strategy, where twelve priority areas for the EU Internal Market have been defined. Single Market Act defined main priorities, as for example access of small and medium sized enterprises to financing, citizens' mobility, intellectual property rights, consumers as single market participants, services, networks, single digital market, social entrepreneurship, taxation, social cohesion, business environment, public procurement, where the set key measures should have been adopted by the end of 2012. The need for evaluation of realized measures at the end of the set period and further decision about next steps were also noted, what indicated future actions. ${ }^{41}$

37 Commission Recommendation of 29 June 2009 on measures to improve the functioning of the single market (Text with EEA relevance), European Commission, document (2009/524/EC), Brussels 2009, online: http://eur-lex. europa.eu/legal-content/EN/TXT/PDF/ ?uri=CELEX:32009H0524\&qid=1473685263349\&from=EN.

38 MONTI, Mario: A New Strategy for the Single Market at the Service of Europe's Economy and Society. Report to the President of the European Commission José Manuel Barroso, 2010, online: http://ec.europa.eu/internal_market/strategy/docs/monti_report_final_10_05_2010_en.pdf.

39 MONTI, 2010.

40 lbidem, 31.

41 Single Market Act Twelve levers to boost growth and strengthen confidence, "Working together to create new growth", Communication from the Commission to the European Parliament, the Council, the Economic and Social Committee and the Committee of the Regions, European Commission, document COM (2011) 206, Brussels 2011, online: http://eur-lex.europa.eu/legal-content/EN/TXT/PDF/?uri=CELEX:52011DC0206\&qid $=1473609125205$ \&from $=$ EN. 
Single Market Act anticipated future actions and they have been implemented in 2012 in the form of the Single Market Act II - Together for new growth (Single Market Act II) adoption. European Commission stated in the Single Market Act II, that the Single Market Act adopted in 2011 was in line with Monti's idea of a necessary comprehensive approach for EU Internal Market completion and for this purpose it defined twelve priorities, most of which haven't been met. European Commission highlighted this fact as one of the reasons for adopting the Single Market Act II and for defining additional priority areas, which were networks integration in the internal market, cross border mobility of citizens and workers, digital economy, social entrepreneurship, cohesion and consumer confidence. ${ }^{42}$

The idea of EU Internal Market completion till the end of 1992, as anticipated by the White Paper and Single European Act, wasn't achieved, but as such it didn't lose significance, because it led and directed the entire European community of countries towards an ideal to be achieved. Adopted strategies repeatedly stated, that some commitments weren't fulfilled. Despite the fact that not all set objectives were achieved, the so far realized steps in EU integration and EU Internal Market completion had positive impacts, both for individual EU Member States as well as for citizens and businesses. ${ }^{43}$ To support the further completion of the EU Internal Market and with regard to the challenges in unemployment, economic and financial crisis, competitiveness of European businesses, economic growth, digital technologies, the European Commission adopted a number of measures, as for example Investment Plan, European Energy Union, Digital Single Market Strategy, Capital Markets Union, Trade for All, Circular Economy package, Labour Mobility package. ${ }^{44}$

\section{Visegrad Group's Role within the EU Internal Market Completion}

Declaration which founded the Visegrad Group in 1991 defined the main objectives of the grouping, which were oriented on democratization processes, removing of remaining totalitarian regime characteristics, development of the rule of law and market economy principles and on the gradual Europeanisation of the political, economic, security and legal system. ${ }^{45}$ Visegrad Group countries did not declare only their will to become a part of the united Europe, but in the declaration from 1991 they stated, that they wanted to actively participate on such a unifying. ${ }^{46}$

After EU accession, which can be according to Strážay considered not only as an achieve-

42 Single Market Act II, Together for new growth, Communication from the Commission to the European Parliament, the Council, the European Economic and Social Committee and the Committee of the Regions, European Commission, document COM (2012) 573 final, online: http://eur-lex.europa.eu/legal-content/EN/TXT/ PDF/?uri=CELEX: 52012DC0573\&qid $=1473609615196 \&$ from $=E N$.

43 RUČINSKÁ - FEČKO, 2012.

44 Upgrading the Single Market: more opportunities for people and business, Communication from the Commission to the European Parliament, the Council, the European Economic and Social Committee and the Committee of the Regions, European Commission, document COM (2015) 550 final, Brussels 2015, online: http://eur-lex. europa.eu/legal-content/EN/ TXT/PDF/?uri=CELEX:52015DC0550\&from=EN.

45 Deklarace o spolupráci České a Slovenské Federativní Republiky, Polské republiky a Mad'arské republiky na cestě evropské integrace, 1991.

46 Ibidem. 
ment of individual countries but also as a result of the overall Visegrad Group, ${ }^{47}$ the Visegrad Group countries jointed the EU Internal Market completion process as full members and co-creators of this process. As newly accessed EU Member States, and it is still the case at present, the Visegrad Group proved itself that their objectives weren't achieved only regarding the EU membership. On the contrary, possibilities and themes for cooperation expanded after the EU accession and the EU membership didn't mean the loss of the Visegrad Groups significance, but a new beginning. ${ }^{48}$ The 2004 declaration of Visegrad Group's prime ministers, which was signed after the EU accession, contained a declaration of willingness to continue within the Visegrad Group cooperation. Visegrad Group countries expressed their readiness to jointly participate in fulfilling of the EU goals, especially in the area of its further enlargement process, helping the EU non-member states seeking to join the EU, by passing their own experiences and knowledge. ${ }^{49}$

Declaration of an active role of the Visegrad Group in the European integration process and EU development have been beneficial also for the completion and enlargement of the EU Internal Market. Visegrad Group countries were in terms of a further and progressive liberalization of free movement of goods, services, capital and person in a position of active EU Member States, which supported this liberalization, as it was in the interest of their own economies but also of their citizens. Declaration of Visegrad Group countries prime ministers in 2011 highlighted the role of the Visegrad Group countries within the economic integration in Europe and regarding the development of four economic freedoms. Visegrad Group countries have wished to continue contributing to the completion of the EU Internal Market, as they were aware of the opportunities in employment, economic cooperation, trade, investments and contact between citizens, what the EU Internal Market has brought to them. ${ }^{50}$

Important role of the Visegrad Group within the EU and from our perspective within the EU Internal Market was stated also in literature. Fawn stressed that even after the EU accession, the Visegrad Group was still viable, had positive and innovative impact for the $\mathrm{EU}$ and in comparison with other, older European groupings of countries, it has a greater seriousness in the Western Europe perspective. ${ }^{51}$ Dangerfield highlighted, that the Visegrad Group does not only represent a closer cooperation of several countries within the EU, but it is an important player in terms of a further integration process and of the overall EU foreign policy. ${ }^{52}$ Securing and further development of the liberalization in the EU Internal

47 STRÁŽAY, Tomáš: Visegrad Four and the Western Balkans: A Group Perspective, in: The Polish Quarterly of International Affairs, 2012, 4, 52-64.

48 DANGERFIELD, 2014, 87.

49 Declaration of Prime Ministers of the Czech Republic, the Republic of Hungary, the Republic of Poland and the Slovak Republic on cooperation of the Visegrád Group countries after their accession to the European Union, 2004.

50 The Bratislava Declaration of the Prime Ministers of the Czech Republic, the Republic of Hungary, the Republic of Poland and the Slovak Republic on the occasion of the 20th anniversary of the Visegrad Group, 2011, online: http://www.visegradgroup.eu/2011/the-bratislava.

51 FAWN, Rick: Visegrad's place in the EU since accession in 2004: "western" perceptions, in: International Issues \& Slovak Foreign Policy Affairs, 23, 2014, 1, 24.

52 DANGERFIELD, 2014, 87. 
Market is also a clear common interest of the Visegrad Group countries ${ }^{53}$, what will lead to an ongoing liberalization of free movement of goods, services, capital and person across the whole EU Internal Market.

However, the Visegrad Group has a great importance not only inside of the EU Internal Market, but can serve as an example for other countries, as for example the Balkan countries, which in the future may enlarge the EU Internal Market. ${ }^{54}$ Regarding the Visegrad Group vs. Balkan countries cooperation Strážay has stated, that the opportunities for an ongoing and closer cooperation are still relevant and that this kind of cooperation is mutually beneficial. ${ }^{55}$ Visegrad Group countries consider themselves in this regard as role models for integration and as countries which can pass their own experiences and good practices regarding the transformation process and the pre and post European accession period. ${ }^{56}$

\section{Conclusion}

EU Internal Market is even thirty years after the adopting of the Single European Act still an uncompleted project. Efforts to fostering the political will for an ongoing delimitation of obstacles in free movement of goods, services, capital and person in the EU Internal Market are repeatedly set. Newly established European Commission under J. C. Juncker considers this also as one of their priorities. Influenced by the unclear conditions of Great Britain leaving the EU, attempts of some leaders mainly from the West European EU Member States trying to establish a so called two-speed Europe, dealing with migration issues, considering the challenges in moving the EU Internal Market into the digital era, is the unity of the EU Member States in political positions and real actions, regarding the EU Internal Market, needed more than ever.

The Visegrad Group was from the beginning and even today it is a grouping of countries, which don't seek to achieve their own goals regardless of the other EU Member States and of the EU Internal Market. On the contrary, even before the $2004 \mathrm{EU}$ accession and also after joining the EU, the Visegrad Group always aimed to contribute to the completion of the EU Internal Market, to be a positive example of cooperation inside the EU Internal Market and beyond the EU Internal market to help the non EU Member States on their European integration path.

\footnotetext{
Abstract

This article points out the role of Visegrad Group countries in the process of European Union Internal Market completion. European Union Internal Market isn't even thirty years after the Single European Act completed and needs to be understood as an ongoing

53 SOBJÁK, 2012, 134

54 ROSTEKOVÁ - ROULET, 2014, 182.

55 STRÁŽAY, 2012, 64.

56 WALSCH, Christopher: Visegrad Four in the European Union. An efficient regional cooperation scheme?, in: International Issues \& Slovak Foreign Policy Affairs, XXIII, 2014, 1-2, 25-41.
} 
process without a possible finish. The future of continuing European Union Internal Market completion is considerably influenced by current developments within the European Union. Protectionist tendencies of national states, the voting of Great Britain to leave the European Union, migration, security issues are testing the solidarity and consistency of the European Union and of its Internal Market. Positive examples of a close cooperation are needed more then before. This article focuses on an analysis of the historical formation of the European Union Internal Market, on identification of the main milestones which influenced this process and on the role of the Visegrad Group countries within this process and as a positive example.

\section{Keywords}

European Union, Internal Market, Visegrad Group, Integration

\section{References}

A single market for $21^{\text {st }}$ century Europe, Communication from the Commission to the European Parliament, the Council, the European Economic and Social Committee and the Committee of the Regions, European Commission, document COM (2007) 724 final, Brussels 2007, online: http://eur-lex.europa.eu/legal-content/EN/TXT/PDF/?uri=CELEX :52007DC0724\&qid $=1473685114116 \&$ from $=E N$.

Action Plan for the Single Market, Communication of the Commission to the European Council, European Commission, document CSE (97) 1 final, Brussels 1997, online: http:// ec.europa.eu/internal_market/strategy/docs/plan_en.pdf.

BRACJUN, Anatolij: Hospodárska politika Európskej únie, Bratislava 2008.

Commission Recommendation of 29 June 2009 on measures to improve the functioning of the single market (Text with EEA relevance), European Commission, document (2009/524/ EC), Brussels 2009, online: http://eur-lex.europa.eu/legal-content/EN/TXT/PDF/?uri=CEL EX:32009H0524\&qid $=1473685263349 \&$ from $=E N$.

Completing the Internal Market. White Paper from the Commission to the European Council, Commission of the European Communities, document COM (85) 310 final, Brussels 1985, online: http://aei.pitt.edu/1113/1/internal_market_wp_COM_85_310.pdf. CZYZ, Anna: What is the Future of the Visegrad Group as an Example of Regional Cooperation, in: Studia Universitatis Babes-Bolyai, Studia Europaea, 52, 2007, 2, 131-144.

DANGERFIELD, Martin: V4: A new brand for Europe? Ten years of post-accession regional cooperation in Central Europe, in: The Poznan University of Economics Review, 14, 2014, 4, 71-90.

Declaration of Prime Ministers of the Czech Republic, the Republic of Hungary, the Republic of Poland and the Slovak Republic on cooperation of the Visegrád Group countries after their accession to the European Union, 2004.

Deklarace o spolupráci České a Slovenské Federativní Republiky, Polské republiky a Mad'arské republiky na cestě evropské integrace, 1991. 
DELANTY, Gerard: Introduction: Perspectives on crisis and critique in Europe today, in: European Journal of Social Theory, 17, 2014, 3, 207-218.

FAWN, Rick: Visegrad's place in the EU since accession in 2004: "western" perceptions, in: International Issues \& Slovak Foreign Policy Affairs, 23, 2014, 1, 3-24.

HOWARTH, David - SADEH, Tal: The ever incomplete single market: differentiation and the evolving frontier of integration, in: Journal of European Public Policy, 17, 2010, 7, 922-935.

HURNÁ, Lucia - RUSIŇÁK, Peter: Právo Európskej únie, Bratislava 2010, 396.

Internal Market Strategy - Priorities 2003-2006, Communication from the Commission to the Council, the European Parliament, the European Economic and Social Committee and the Committee of the Regions, European Commission, document COM (2003) 238 final, Brussels 2003, online: http://eur-lex.europa.eu/legal-content/EN/TXT/PD F/?uri=CELEX: 52003DC0238\&qid $=1473685001362 \&$ from $=E N$.

JANKŮ, Martin - JANKUீ, Linda: Politické a právní základy evropských integračních seskupení, Praha 2010, 256.

JANKÜ, Martin - JANKÜ Linda: Právo EU po Lisabonské smlouvě, Ostrava 2012, 275.

KALESNÁ, Katarína - HRUŠKOVIČ, Ivan - ĎURIŠ, Michal: Európske právo, Bratislava 2011, 247.

LIPKOVÁ, Ĺudmila a kol.: Európska únia, Bratislava 2011, 448.

LOCKWOOD, Ben - MIGALI, Giuseppe: Did The Single Market Cause Competition in

Excise Taxes? Evidence From EU Countries, in: Economic Journal, 119, 2009, 536, 406429.

MCNAUGHTON, Anne: Integrating services markets: a comparison of European Union and Australian experiences, in: Australian Journal of International Affairs, 65, 2011, 4, 454468.

MONTI, Mario: A New Strategy for the Single Market at the Service of Europe's Economy and Society. Report to the President of the European Commission José Manuel Barroso, 2010, online: http://ec.europa.eu/ internal_market/strategy/docs/monti_report_ final_10_05_2010_en.pdf.

ROSTEKOVÁ, Maria - ROUET, Gilles: The Visegrád Group - a Model to Follow?, in: Politeja, 28, 2014, 181-193.

RUČINSKÁ, Silvia - FEČKO Miroslav: Vnútorný trh Európskej únie - sme v súčasnosti bez hraníc?, in: Integrovaná Evropa současnosti a budoucnosti - Reflexe třiceti let od podpisu Schengenské úmluvy, PÁNA, Lubomír a kol., České Budějovice 2015, 55-63.

RUČINSKÁ, Silvia - FEČKO Miroslav: Vnútorný trh Európskej únie z pohladu jeho dvadsat'ročnej existencie, in: Aktuálne problémy a výzvy verejnej správy: recenzovaný zborník z vedeckej konferencie s medzinárodnou účastou konanej dňa 21. novembra 2012 v Košiciach, Košice 2012, 205-213.

Single European Act 1986.

Single Market Act Twelve levers to boost growth and strengthen confidence, "Working together to create new growth", Communication from the Commission to the European Parliament, the Council, the Economic and Social Committee and the Committee of the Regions, European Commission, document COM (2011) 206, Brussels 2011, online: http://eur-lex.europa.eu /legal-content/EN/TXT/PDF/?uri=CELEX:52011D 
C0206\&qid $=1473609125205$ \&from $=E N$.

Single Market Act II, Together for new growth, Communication from the Commission to the European Parliament, the Council, the European Economic and Social Committee and the Committee of the Regions, European Commission, document COM (2012) 573 final, Brussels 2011, online: http://eur-lex.europa.eu/legal-content/EN/TXT/PD F/?uri=CELEX :52012DC0573\&qid=1473609615196\&from=EN.

SOBJÁK, Anita: Rethinking the future of the Visegrad group at a time of heated debate on the future of the EU, in: The Polish Quarterly of International Affairs, 21, 2012, 4, 122-139.

STRÁŽAY, Tomáš: Visegrad Four and the Western Balkans: A Group Perspective, in: The Polish Quarterly of International Affairs, 2012, 4, 52-64.

STRÁŽNICKÁ, Viera: Európska integrácia a právo Európskej únie, Bratislava 2009, 312.

Text of the Modified Brussels Treaty 1954, online: http://www.weu.int/Treaty.htm\#1.

TICHÝ, Luboš et al.: Evropské právo, Praha 2011, 953.

Treaty Establishing the European Economic Community 1957.

Treaty on European Union (Consolidated version).

Treaty on the Functioning of the European Union (Consolidated version).

The Bratislava Declaration of the Prime Ministers of the Czech Republic, the Republic of Hungary, the Republic of Poland and the Slovak Republic on the occasion of the $20^{\text {th }}$ anniversary of the Visegrad Group, 2011, online: http://www.visegradgroup.eu/2011/ the-bratislava.

The Schuman Declaration 1950, in: From The Schuman Declaration to the birth of the ECSC: The role of Jean Monnet, PIODI, Franco (ed.), Luxemburg 2010.

The strategy for Europe's Internal Market, Communication from the Commission to the European Parliament and the Council, European Commission, document COM (1999) 624 final/2, Brussels 1999, online: http://eur-lex.europa.eu/legalcontent/EN/TXT/PD $\mathrm{F} /$ ?uri= CELEX:51999DC0624\&qid $=1473684859494 \&$ from $=E N$.

Upgrading the Single Market: more opportunities for people and business, Communication from the Commission to the European Parliament, the Council, the European Economic and Social Committee and the Committee of the Regions, European Commission, document COM (2015) 550 final, Brussels 2015, online: http://eur-lex.euro pa.eu/legal-content/EN/TXT/PDF/?uri=CELEX :52015DC0550\&from=EN.

Vertrag über die Gründung der Europäischen Gemeinschaft für Kohle und Stahl 1951.

WALSCH, Christopher: Visegrad Four in the European Union. An efficient regional cooperation scheme?, in: International Issues \& Slovak Foreign Policy Affairs, XXIII, 2014, $1-2,25-41$. 